\title{
PENGUKURAN KINERJA PORTOFOLIO OPTIMAL SAHAM LQ45 MENGGUNAKAN METODE CAPITAL ASSET PRICING MODEL (CAPM) DAN LIQUIDITY ADJUSTED CAPITAL ASSET PRICING MODEL (LCAPM)
}

\author{
Kristika Safitri $^{1}$, Tarno $^{2}$, Abdul Hoyyi ${ }^{3}$ \\ 1,2,3 Departemen Statistika, Fakultas Sains dan Matematika, Universitas Diponegoro \\ e-mail: kristikaaf08@gmail.com
}

\begin{abstract}
Investment is planting some funds to get profit and the stock is one of the type of investment in fincancial that the most interested for investors. To avoid the risk of investing, investors try to diversify their invesments by using portfolio. Stock portfolio is investment which comprised of various stocks from different companies, with the expect when the price of one stock decreases, while the other increases, then the investments do not suffer losses. Models that can be used to make a portfolio, one of them is Capital Asset Pricing Model (CAPM) and Liquidity Adjusted Capital Asset Pricing Model (LCAPM). CAPM is a model that connects expected return with the risk of an asset under market equilibrium condition. LCAPM is a method of new development of the CAPM model which is influenced by liquidity risk. To analyze whether the formed portfolio have a good performance or not, so portfolio perfomance assessment will be done by using The Sharpe Index. This research uses data from closing prices, transaction volume and volume total of LQ45 Index stock on period March 2016-February 2020 and then data of JCI and interest rate of central bank of the Republic of Indonesia. Based on The Sharpe Index, optimal portfolio is LCAPM model portfolio with 3 stock composition and the proportion investment are 32,39\% for LPPF, 49,86\% for SRIL and $17,75 \%$ for TLKM.
\end{abstract}

Keywords : LQ45 Index, Portfolio, Capital Asset Pricing Model (CAPM), Liquidity Adjusted Capital Asset Pricing Model (LCAPM), The Sharpe Index.

\section{PENDAhUluan}

Pasar modal merupakan pasar untuk berbagai instrumen keuangan jangka panjang yang bisa diperjualbelikan, baik surat utang (obligasi), ekuitas (saham), maupun instrumen lainnya. Saham merupakan salah satu instrumen dari pasar modal yang paling banyak diminati oleh masyarakat, hal ini dibuktikan dengan naiknya nilai Indeks Harga Saham Gabungan (IHSG) dari tahun ke tahun. Saham adalah surat berharga sebagai bukti kepemilikan suatu perusahaan. Jika perusahaan memperoleh keuntungan, maka setiap pemegang saham berhak atas bagian laba yang dibagikan atau dividen sesuai dengan proposal kepemilikannya (Zubir, 2013). Investasi adalah menempatkan uang atau dana dengan harapan untuk memperoleh tambahan atau keuntungan tertentu atas uang atau dana tersebut (Ahmad, 2004). Pasar modal merupakan salah satu tempat sarana berinvestasi dalam bidang finansial yang menarik bagi investor. Menurut Harry M. Markowitz dalam Anoraga dan Pakarti (2006), investor termasuk dalam risk averter yang artinya investor akan selalu berusaha untuk dapat menghindari risiko. Untuk menghindari risiko, maka investor mencoba untuk melakukan diversifikasi investasi. Konsep diversifikasi yang biasa digunakan adalah portofolio. Zubir (2013) menjelaskan bahwa Portofolio saham adalah investasi yang terdiri dari berbagai saham perusahaan yang berbeda, dengan harapan bila harga salah satu saham menurun, sementara yang lain meningkat, maka investasi tersebut tidak mengalami kerugian. Ada berbagai model yang bisa digunakan dalam pembentukan portofolio salah satunya adalah CAPM dan LCAPM. Capital Asset Pricing Model (CAPM) adalah sebuah model hubungan antara risiko dan expected return suatu portofolio (Zubir, 2013). Berdasarkan CAPM return yang diharapkan ditentukan oleh return bebas risiko dan risiko sistematis (beta). Sedangkan Liquidity Adjusted Capital Asset Pricing Model (LCAPM) merupakan metode pengembangan baru dari CAPM yang dipengaruhi likuiditas, yaitu 
apabila indikator likuiditas digabungkan dengan metode CAPM dapat membantu memaksimalkan return dan meminimumkan risiko. Sehingga dalam penelitian ini difokuskan pada penggunaan Capital Asset Pricing Model (CAPM) dan Liquidity Adjusted Capital Asset Pricing Model (LCAPM).

Peneliti sebelumnya pernah mengembangkan penelitian tentang portofolio model CAPM dan portofolio model LCAPM. Apriyanti dan Supandi (2019) melakukan penelitian tentang perbandingan model Capital Asset Pricing Model (CAPM) dan Liquidity Adjusted Capital Asset Pricing Model (LCAPM) dalam pembentukan portofolio optimal dengan objek penelitian data closing price bulanan saham Jakarta Islamic Index periode April 2015 hingga April 2018. Pada penelitian sebelumnya objek yang digunakan, yaitu saham Jakarta Islamic Index, sedangkan pada penelitian ini objek yang akan digunakan yaitu saham indeks LQ45. Saham Indeks LQ45 ini dibentuk dari 45 saham yang paling aktif diperdagangkan dan pertimbangan yang mendasari pemilihan saham yang masuk di indeks LQ45 yaitu perusahaan yang memiliki likuiditas tinggi dan kapitalisasi pasar terbesar.

Berdasarkan uraian di atas, penulis akan membahas portofolio model CAPM dan model LCAPM sekaligus mengukur kinerja dari kedua model portofolio tersebut dan menerapkannya pada data closing price bulanan saham LQ45 periode September 2015 Februari 2020. Tujuan dari analisis kinerja portofolio adalah untuk mengetahui apakah portofolio yang dibentuk telah dapat meningkatkan kemungkinan tercapainya tujuan investasi (Halim, 2005). Metode pengukuran yang digunakan adalah The Sharpe Index. The Sharpe Index ini relevan dipergunakan untuk investor yang menanamkan dananya pada portofolio, sehingga risiko portofolio dinyatakan dalam standar deviasi. Portofolio yang mempuyai rasio terbesar dinilai mempunyai kinerja yang lebih baik.

\section{TINJAUAN PUSTAKA}

\subsection{Return}

Return merupakan salah satu faktor yang memotivasi investor untuk berinvestasi karena return merupakan hasil yang diperoleh dari investasi (Jogiyanto, 2010). Return diartikan sebagai keuntungan atau kerugian suatu investasi dalam periode tertentu (Zulfikar, 2016).

Dengan:

$$
R_{i, t}=\ln \left(\frac{P_{i, t}}{P_{i,(t-1)}}\right)
$$

$$
\begin{array}{ll}
R_{i, t} & : \text { return aset ke- } i \text { pada waktu ke- } t \\
P_{i, t} & : \text { harga aset ke- } i \text { pada waktu ke- } t \\
P_{t-1} & : \text { harga aset ke- } i \text { pada waktu ke- }(t-1)
\end{array}
$$

\subsection{Uji Asumsi Normal Univariat}

Pengujian asumsi normal univariat dilakukan pada sebuah variabel. Uji yang umum digunakan adalah uji Kolmogorov-Smirnov.

Data terdiri dari sampel random $X_{1}, X_{2}, \ldots, X_{n}, X_{n}$ yang belum diketahui fungsi distribusi kumulatifnya, dinotasikan dengan $F(x), F_{0}(x)$ adalah fungsi distribusi kumulatif dari distribusi yang dihipotesiskan (Daniel, 1978).

Hipotesis:

$H_{0}: F(x)=F_{0}(x)$ untuk semua $x$ dari $-\infty$ sampai $\infty$

(Data berdistribusi yang dihipotesiskan)

$H_{1}: F(x) \neq F_{0}(x)$ untuk sekurang-kurangnya sebuah nilai $x$

(Data tidak berdistribusi yang dihipotesiskan)

Tingkat signifikansi : $\alpha$

Statistik Uji 
dimana

$$
\mathrm{D}=\operatorname{Sup}_{x}\left|S(x)-F_{0}(x)\right|
$$

D : nilai supremum untuk semua $x$ dari nilai mutlak beda $S(x)-F_{0}(x)$

$S(x)$ : fungsi distribusi kumulatif data sampel

Kriteria Uji

$H_{0}$ ditolak jika $\mathrm{D}>\mathrm{D}^{*}(\alpha)$. $\mathrm{D}^{*}(\alpha)$ merupakan nilai kritis yang diperoleh dari tabel

"Kolmogorov-Smirnov" atau Ho ditolak jika $p$-value $<\alpha$.

\subsection{Portofolio}

Zubir (2013) menjelaskan bahwa Portofolio saham adalah investasi yang terdiri dari berbagai saham perusahaan yang berbeda, dengan harapan bila harga salah satu saham menurun, sementara yang lain meningkat, maka investasi tersebut tidak mengalami kerugian.

Return realisasi portofolio (portfolio realized return) merupakan rata-rata tertimbang dari return-return realisasi masing-masing saham tunggal di dalam portofolio tersebut (Jogiyanto, 2017). Secara matematis, return realisasi portofolio dapat ditulis sebagai berikut:

$$
R_{p}=\sum_{i=1}^{n}\left(w_{i} \cdot R_{i}\right)
$$

Keterangan:

$R_{p} \quad$ : return realisasi portofolio

$w_{i} \quad$ : bobot dari saham ke- $i$ terhadap seluruh saham di portofolio

$R_{i} \quad$ : return realisasi dari saham ke- $i$

n : banyaknya saham

Sedangkan expected return portofolio merupakan rata-rata tertimbang dari expected return masing-masing saham tunggal di dalam portfofolio. Expected return portofolio dapat dinyatakan secara matematis sebagai berikut:

$$
\mathrm{E}[\mathrm{Rp}]=\frac{\sum_{j=1}^{k}\left(\sum_{i=1}^{n}\left(w_{i} \cdot R_{i}\right)\right)}{k}
$$

Keterangan:

$\mathrm{E}(\mathrm{Rp})$ : expected return dari portofolio

$w_{i} \quad$ : bobot dari saham ke- $i$ terhadap seluruh saham di portofolio

$R_{i} \quad$ : return realisasi dari saham ke- $i$

n : banyaknya saham

$\mathrm{k} \quad$ : banyaknya data return saham

Kovarian dalam manajemen portofolio adalah sejauh mana return dari kedua saham mempunyai kecenderungan bergerak bersama-sama. Kovarian bernilai positif, artinya kecenderungan dua saham bergerak dalam arah yang sama, jika return saham A naik, maka return saham B juga akan naik. Kovarian bernilai negatif, artinya kecenderungan dua saham bergerak dalam arah yang berbeda, jika return saham A naik, maka return saham B akan turun. Kovarian bernilai nol, artinya pergerakan dua saham saling indepeden satu sama lain.

Kovarian dua saham dapat ditulis sebagai berikut:

$\operatorname{Cov}(\mathrm{A}, \mathrm{B})=\frac{\sum_{t=1}^{N}\left[\left(R_{A t}-\mu_{A}\right)\left(\left(R_{B t}-\mu_{B}\right)\right]\right.}{N-1}$

Keterangan :

$R_{A t}:$ Return saham A pada waktu ke-t

$\mu_{A}$ : Rata-rata return saham A

$R_{B t}:$ Return saham B pada waktu ke-t

$\mu_{B}:$ Rata-rata return saham B

$N$ : Banyak data return 


\subsection{Pembentukan Portofolio Model Capital Asset Pricing Model (CAPM)}

Capital Asset Pricing Model (CAPM) pertama kali diperkenalkan oleh William Sharpe, John Lintner, dan Jan Mossin pada pertengahan tahun 1960-an. CAPM adalah model keseimbangan yang menggambarkan hubungan risiko dan return secara lebih sederhana, dan hanya menggunakan suatu variabel (beta) untuk menggambarkan risiko (Zulfikar, 2016). Beta merupakan suatu pengukur votalitas return suatu sekuritas atau return portofolio terhadap return pasar (Tandelilin, 2010). Kodrat (2010) menyatakan bahwa, menurut CAPM, jika risiko diukur dengan beta, hubungan antara risiko yang relevan dari suatu saham dengan expected return yang diisyaratkan dengan suatu garis linier yang disebut Security Market Line (SML) dengan persamaan sebagai berikut:

$$
E\left(R_{i}\right)=\bar{R}_{b r}+\beta_{i}\left(E\left(R_{m}\right)-\bar{R}_{b r}\right)
$$

Dengan:

$$
\beta_{i}=\frac{\operatorname{cov}\left(R_{i}, R_{m}\right)}{\operatorname{var}\left(R_{m}\right)} \quad ; \mathrm{i}=1,2, \ldots, \mathrm{n}
$$

Keterangan:

$E\left(R_{i}\right)$ : expected return saham ke- $i$

$\bar{R}_{b r} \quad$ : rata-rata return bebas risiko

$E\left(R_{m}\right):$ expected return pasar

$\beta_{i} \quad$ : beta (ukuran risiko) saham ke- $i$

$R_{i} \quad$ : return saham

$R_{m} \quad$ : return pasar

Untuk portofolio dengan menggunakan model CAPM, Apriyanti dan Supandi (2019) menentukan besarnya bobot investasi dengan persamaan:

$$
\boldsymbol{y}=\left(\sum\right)^{-1}\left(\boldsymbol{E}\left(\boldsymbol{R}_{\boldsymbol{i}}\right)-\overline{\boldsymbol{R}}_{\boldsymbol{b r}}\right)
$$

Jumlahan elemen dari vektor $\boldsymbol{y}$ yang ada tidak selalu bernilai 1, maka perlu dinormalisasi dengan:

Dengan:

$$
w=\frac{y}{\sum_{i=1}^{n} y_{i}}
$$

$\boldsymbol{w} \quad$ : matriks pembobot investasi yang berukuran $\mathrm{n} \times 1$ dan jika elemen matriksnya dijumlahkan maka akan bernilai 1

$y_{i} \quad$ : bobot investasi saham ke- $i$, dengan $i=1,2, \ldots, n$

$\sum \quad$ : matriks varian kovarian dari $\mathrm{k}$ return saham penyusun portofolio, sehingga berukuran $\mathrm{n} \times \mathrm{n}$

$\mathbf{E}\left(\boldsymbol{R}_{\boldsymbol{i}}\right)$ : matriks expected return dari model CAPM dengan $i=1,2, \ldots, n$, sehingga berukuran $\mathrm{n} \times 1$

$\overline{\boldsymbol{R}}_{\boldsymbol{b r}} \quad$ : matriks berukuran $\mathrm{n} \times 1$ yang semua elemennya bernilai sama, yaitu nilai rata-rata return bunga investasi bebas risiko

\subsection{Likuiditas Saham}

Likuiditas menurut Bursa Efek Indonesia adalah kelancaran yang menunjukkan tingkat kemudahan dalam mencairkan modal investasi. Pengukuran likuiditas saham dilakukan dengan melihat Trading Volume Activity (TVA). Trading Volume Activity (TVA) merupakan suatu instrumen yang dapat digunakan untuk melihat reaksi pasar terhadap suatu informasi melalui parameter pergerakan aktivitas volume perdagangan dipasar modal (Mulyana, 2011). Likuiditas saham diperoleh dengan rumus sebagai berikut:

$$
C_{i}=\frac{\text { Jumlah Volume Transaksi }}{\text { Total Volume Saham }}
$$


Sedangkan likuiditas pasar adalah nilai likuiditas yang diperoleh berdasarkan volume transaksi pasar suatu lembar saham yang terdapat pada IHSG (total volume pasar). Likuiditas pasar diperoleh dengan rumus sebagai berikut:

$$
C_{m}=\frac{\text { Jumlah Volume Transaksi Pasar pada IHSG }}{\text { Total Volume Pasar pada IHSG }}
$$

\subsection{Pembentukan Portofolio Model Liquidity Adjusted Capital Asset Pricing Model (LCAPM)}

LCAPM pertama kali dikembangkan oleh Archarya dan Pedersen pada tahun 2005. Asumsi LCAPM sama dengan CAPM yaitu memiliki pasar modal dalam kondisi pasar yang seimbang. Perbedaannya adalah model LCAPM dipengaruhi oleh risiko likuiditas. Metode LCAPM dipengaruhi oleh empat beta antara lain $\beta_{1 i}$ digunakan untuk mengukur return saham terhadap return pasar, $\beta_{2 i}$ digunakan untuk mengukur likuiditas saham terhadap likuiditas pasar, $\beta_{3 i}$ digunakan untuk mengukur return saham terhadap likuiditas pasar dan $\beta_{4 i}$ digunakan untuk mengukur likuiditas saham terhadap return pasar (Cahyati, 2015). Secara umum, persamaan model LCAPM sebagai berikut:

$$
\mathrm{E}\left(R_{i}\right)=\bar{R}_{b r}+E\left(C_{i}\right)+\lambda_{c}\left(\beta_{1 i}+\beta_{2 i^{-}} \beta_{3 i^{-}} \beta_{4 i}\right)
$$

Dengan:

$$
\begin{aligned}
C_{i} & =\frac{\text { Jumlah Volume Transaksi }}{\text { Total Volume Saham }} \\
\lambda_{c} & =\mathrm{E}\left(R_{m}-C_{m}-R_{\text {br }}\right) \\
C_{m} & =\frac{\text { Jumlah Volume Transaksi Pasar pada IHSG }}{\text { Total Volume Pasar pada IHSG }} \\
\beta_{1 i} & =\frac{\operatorname{cov}\left(R_{i}, R_{m}\right)}{\operatorname{var}\left(R_{m}-C_{m}\right)} \quad ; i=1,2, \ldots, n \\
\beta_{2 i} & =\frac{\operatorname{cov}\left(C_{i}, C_{m}\right)}{\operatorname{var}\left(R_{m}-C_{m}\right)} \quad ; i=1,2, \ldots, n \\
\beta_{3 i} & =\frac{\operatorname{cov}\left(R_{i}, C_{m}\right)}{\operatorname{var}\left(R_{m}-C_{m}\right)} \quad ; i=1,2, \ldots, n \\
\beta_{4 i} & =\frac{\operatorname{cov}\left(C_{i}, R_{m}\right)}{\operatorname{var}\left(R_{m}-C_{m}\right)} \quad ; i=1,2, \ldots, n
\end{aligned}
$$

Keterangan:

$\mathrm{E}\left(R_{i}\right)$ : expected return saham ke- $i$

$\bar{R}_{b r}$ : rata-rata return bebas risiko

$E\left(C_{i}\right)$ : expected likuiditas saham ke- $i$

$\lambda_{c} \quad$ : lambda likuiditas

$\beta_{1 i}$ : beta (ukuran risiko) 1 saham ke- $i$

$\beta_{2 i}$ : beta (ukuran risiko) 2 saham ke- $i$

$\beta_{3 i}$ : beta (ukuran risiko) 3 saham ke- $i$

$\beta_{4 i}$ : beta (ukuran risiko) 4 saham ke- $i$

$R_{i} \quad$ : return saham ke- $i$

$R_{m} \quad$ : return pasar

$C_{i} \quad$ : likuiditas saham ke- $i$

$C_{m} \quad$ : likuiditas pasar

Pembentukan portofolio yang optimal, seorang investor tentunya harus menentukan bobot investasi yang akan ditanamkan ke saham-saham yang membentuk portofolio. Untuk portofolio dengan menggunakan model LCAPM, Cahyati (2009) menentukan besarnya bobot investasi dengan persamaan:

$$
\boldsymbol{z}=\left(\sum\right)^{-1}\left(\boldsymbol{E}(\boldsymbol{R}-\boldsymbol{C})-\overline{\boldsymbol{R}}_{\boldsymbol{b r}}\right)
$$

Jumlahan elemen dari vektor $\boldsymbol{z}$ yang ada tidak selalu bernilai 1, maka perlu dinormalisasi dengan: 
$\boldsymbol{w}=\frac{z}{\sum_{i=1}^{k} z_{i}}$

Dengan:

$\boldsymbol{w} \quad$ : matriks pemobobot investasi yang berukuran $\mathrm{n} \times 1$ dan jika elemen vektornya dijumlahkan maka akan bernilai 1

$z_{i} \quad$ : bobot investasi saham ke- $i$, dengan $i=1,2, \ldots, n$

$\sum \quad:$ matriks varian kovarian dari k likuiditas saham penyusun portofolio, sehingga berukuran $\mathrm{n} \times \mathrm{n}$

$\boldsymbol{E}(\boldsymbol{R}-\boldsymbol{C})$ : matriks expected dari selisih return dan likuiditas saham dari model LCAPM dengan $i=1,2, \ldots, n$, sehingga berukuran $\mathrm{n} \times 1$

$\overline{\boldsymbol{R}}_{\boldsymbol{b r}} \quad$ : matriks berukuran $\mathrm{n} \times 1$ yang semua elemennya bernilai sama, yaitu nilai ratarata return bunga investasi bebas risiko

\subsection{Kinerja Portofolio}

Menurut Suad Husnan (1996) penilaian kinerja perlu dilakukan untuk menentukan apakah pilihan investasi memberikan hasil terbaik atau tidak. The Sharpe Index menyatakan kinerja portofolio dihitung berdasarkan hasil bersih dari portofolio dengan tingkat bunga bebas risiko dan diberi simbol Sp. Portofolio yang mempunyai rasio terbesar dinilai mempunyai kinerja terbaik. The Sharpe Index dapat dihitung dengan formula sebagai berikut (Azis et al., 2015) :

$$
S_{p}=\frac{\bar{R}_{p}-R_{b r}}{\sigma_{p}}
$$

Keterangan:

$S_{p}:$ The Sharpe Index

$\bar{R}_{p}$ : rata-rata return portofolio

$\bar{R}_{b r}$ : rata-rata return bebas risiko

$\sigma_{p}:$ standar deviasi dari return portofolio

\section{METODE PENELITIAN}

Jenis data yang digunakan dalam penelitian ini adalah data sekunder. Data ini merupakan data closing price saham anggota indeks LQ45 yang diperoleh dari www.finance.yahoo.com serta jumlah volume transaksi bulanan dan total volume saham anggota indeks LQ45 yang diperoleh dari www.finance.yahoo.com dan www.idx.co.id. Data lain yang digunakan, yaitu data Indeks Harga Saham Gabungan (IHSG) dan data tingkat suku bunga Bank Indonesia yang diperoleh dari situs resmi Bank Indonesia yaitu www.bi.go.id. Sedangkan periode yang digunakan adalah sepanjang September 2015 Februari 2020 dalam bulanan.

Tahap-tahap analisis data yang dilaksanakan sebagai berikut:

1. Pengumpulan data harga penutupan saham (closing price) dan jumlah volume transaksi serta total volume saham Indeks LQ45, Indeks Harga Saham Gabungan (IHSG), dan return bebas risiko dengan keseluruhan data berperiode waktu September 2015 Februari 2020 dalam bulanan.

2. Menghitung return dari data harga penutupan saham (closing price) Indeks LQ45 dan Indeks Harga Saham Gabungan (IHSG).

3. Menghitung likuiditas saham terpilih dari data jumlah volume transaksi dan total volume saham Indeks LQ45 dan likuiditas Indeks Harga Saham Gabungan (IHSG).

4. Menghitung expected return pasar.

5. Menghitung nilai Beta setiap saham indeks LQ45.

6. Menghitung expected return setiap saham indeks LQ45.

7. Seleksi Saham menggunakan CAPM 
8. Pengujian normalitas dari return saham indeks LQ45 yang terpilih menggunakan Uji Kolmogorov-Smirnov. Syarat penyusunan portofolio adalah asumsi normalitas univariat dari masing-masing aset saham harus terpenuhi.

9. Memilih saham terbaik pada saham indeks LQ45 menggunakan CAPM.

10. Menghitung expected likuiditas setiap saham terpilih.

11. Menghitung lambda Likuiditas.

12. Menghitung nilai Beta Likuiditas setiap saham terpilih.

13. Menghitung expected return setiap saham terpilih.

14. Menentukan bobot optimal aset portofolio menggunakan metode Capital Asset Pricing Model (CAPM) dan Liquidity Adjusted Capital Asset Pricing Model (LCAPM).

15. Membentuk portofolio optimal berdasarkan saham terpilih menggunakan metode Capital Asset pricing Model (CAPM) dan Liquidity Adjusted Capital Asset Pricing Model (LCAPM).

16. Melakukan analisis kinerja portofolio dengan menggunakan metode The Sharpe Index.

\section{HASIL DAN PEMBAHASAN}

\subsection{Deskripsi Data, Perhitungan Return dan Likuiditas Saham}

Data yang digunakan adalah data return saham dengan jumlah observasi sebanyak 24 data. Data harga penutupan saham yang digunakan merupakan saham-saham yang terdaftar dalam Indeks LQ45. Selain itu terdapat pula data lain yang digunakan, yaitu Indeks Harga Saham Gabungan (IHSG), Suku Bunga Bank Indonesia (SBI), jumlah volume transaksi dan total volume saham terbaik serta jumlah volume transaksi pasar dan total volume pasar pada IHSG. Setelah semua data didapatkan, langkah selanjutnya adalah menghitung return dari masing-masing saham indeks LQ45 dan return Indeks Harga Saham Gabungan serta likuiditas dari masing-masing saham terbaik dan likuiditas Indeks Harga Saham Gabungan (IHSG).

\subsection{Pemilihan Saham Penyusun Portofolio Menggunakan CAPM}

Dalam pembentukan portofolio model CAPM, terlebih dahulu dihitung beta dari masing-masing saham $\left(\beta_{i}\right)$ dengan menggunakan rumus

$$
\beta_{i}=\frac{\operatorname{cov}\left(R_{i}, R_{m}\right)}{\operatorname{var}\left(R_{m}\right)} \quad ; \mathrm{i}=1,2,3, \ldots, 26
$$

Dengan :

$\beta_{i} \quad:$ Beta saham ke-i

$\operatorname{cov}\left(R_{i}, R_{m}\right)$ : Kovarian antara return saham ke-i dan return pasar $\operatorname{var}\left(R_{m}\right) \quad$ : Varian return pasar

Beta suatu saham sama dengan 1 berarti saham tersebut memiliki risiko yang sama dengan risiko rata-rata pasar. Beta suatu saham kurang dari 1 berarti saham tersebut memiliki risiko di bawah risiko rata-rata pasar. Sedangkan beta suatu saham lebih besar dari 1 berarti saham tersebut memiliki risiko di atas risiko rata-rata pasar.

Kemudian menghitung expected return dari masing-masing saham dengan menggunakan rumus

$\mathrm{E}\left(R_{i}\right)=R_{b r}+\beta_{i}\left(\mathrm{E}\left(R_{m}\right)-R_{b r}\right)$

Data $R_{b r}$ yang digunakan adalah data Suku Bunga Bank Indonesia (SBI) sedangkan $\mathrm{E}\left(R_{m}\right)$ yang digunakan adalah data Indeks Harga Saham Gabungan (IHSG).

\subsubsection{Saham Terbaik Model CAPM}

Saham-saham yang dipilih dalam portofolio ini adalah saham-saham yang memiliki rasio di bawah risiko rata-rata pasar $(\beta<1)$ dan dalam berinvestasi seorang investor pasti mengharapkan keuntungan terbesar, oleh karena itu akan diambil saham yang memiliki risiko di bawah rata-rata risiko pasar dan memiliki expected return terbesar. Pada penelitian 
ini peneliti ingin membentuk portofolio saham yang terdiri dari tiga saham penyusun, sehingga akan diambil tiga saham terbaik berdasarkan kriteria tersebut yang dapat dilihat pada Tabel 1.

Tabel 1. Saham Terbaik Model CAPM

\begin{tabular}{cccc}
\hline No. & Kode Saham & Beta & Expected Return \\
\hline 1 & LPPF & $-0,0197$ & 0,0554 \\
2 & SRIL & 0,6632 & 0,0215 \\
3 & TLKM & 0,5484 & 0,0272
\end{tabular}

Menurut Halim (2005), saham yang dipilih dalam pembentukan portofolio adalah saham-saham yang mempunyai return yang berkovarian negatif (mempunyai pergerakan berlawanan). Hal ini dilakukan karena dapat menurunkan risiko. Berdasarkan uraian tersebut, dilakukan perhitungan varian kovarian pada return dari tiga saham dengan expected return terbesar dan diperoleh hasil yang dapat dilihat pada tabel 2 .

Tabel 2. Varian Kovarian Return Saham

\begin{tabular}{cccc}
\hline & LPPF & SRIL & TLKM \\
\hline LPPF & 0,01687 & $-0,0041$ & $-0,0005$ \\
SRIL & $-0,0041$ & 0,0123 & $-0,0002$ \\
TLKM & $-0,0005$ & $-0,0002$ & 0,0031
\end{tabular}

Berdasarkan Tabel 2, kovarian return saham LPPF dan SRIL, LPPF dan TLKM, serta SRIL dan TLKM bernilai negatif, sehingga Saham LPPF, SRIL dan TLKM dapat digunakan dalam pembentukan portofolio.

\subsubsection{Pengujian Normalitas Univariat}

Hasil dari pengujian normalitas ketiga return saham Indeks LQ45 pada taraf signifikansi $\alpha=5 \%$, yang dilakukan dengan menggunakan uji Kolmogorov-Smirnov secara univariat dan diolah dengan program $\mathrm{R}$, maka diperoleh hasil pada tabel 3.

Tabel 3. Keputusan Uji Kolmogorov-Smirnov

\begin{tabular}{ccccc}
\hline No. & Kode Saham & $P$-value & Keputusan & Asumsi Normalitas \\
\hline 1 & LPPF & 0,200 & $H_{0}$ diterima & Terpenuhi \\
2 & SRIL & 0,064 & $H_{0}$ diterima & Terpenuhi \\
3 & TLKM & 0,454 & $H_{0}$ diterima & Terpenuhi \\
\hline
\end{tabular}

Berdasarkan Tabel 3, kode emiten LPPF, SRIL dan TLKM memiliki return yang berdistribusi normal. Pemilihan saham dengan return yang berdistribusi normal bertujuan untuk menghindari adanya data outlier. Data outlier merupakan data yang berbeda secara signifikan dari data pengamatan lainnya dengan jumlah frekuensi yang sangat sedikit. Sehingga dengan return saham yang berdistribusi normal diharapkan tidak ada return saham pada periode tertentu yang akan menyebabkan ketidakstabilan harga saham yang dikarenakan adanya return saham yang berbeda secara signifikan. Sehingga dalam penelitian ini, saham yang dapat dianalisis lebih lanjut yaitu saham dengan kode emiten LPPF, SRIL dan TLKM.

\subsubsection{Pembentukan Bobot Optimal}

Dengan menggunakan bantuan program R, diperoleh hasil seperti pada Tabel 4.

Tabel 4. Bobot Saham Optimal Masing-masing Saham

\begin{tabular}{ccc}
\hline No & Saham & Bobot \\
\hline 1 & LPPF & 0,0757 \\
2 & SRIL & 0,2362 \\
3 & TLKM & 0,6881 \\
\hline
\end{tabular}


Berdasarkan tabel 4 dapat diketahui bahwa investor akan menginvestasikan dananya sebesar 7,57\% ke saham LPPF, sebesar 23,62\% ke saham SRIL dan sebesar 68,81\% ke saham TLKM.

\subsection{Pemilihan Saham Penyusun Portofolio Menggunakan LCAPM}

Dalam penelitian ini dikarenakan tidak ada kriteria tertentu dalam memilih saham yang akan digunakan untuk portofolio maka peneliti akan memilih tiga saham yang sama dengan saham yang digunakan dalam metode sebelumnya. Sehingga diperoleh saham yang terpilih adalah LPPF, SRIL dan TLKM.

\subsubsection{Beta Likuiditas}

Dalam pembentukan portofolio model CAPM, terlebih dahulu dihitung beta dari masing-masing saham $\left(\beta_{1 i}, \beta_{2 i}, \beta_{3 i}\right.$ dan $\left.\beta_{4 i}\right)$. Dengan menggunakan bantuan program $\mathrm{R}$, diperoleh hasil perhitungan beta likuiditas dari masing-masing saham seperti pada Tabel 5 .

Tabel 5. Beta Likuiditas Model LCAPM

\begin{tabular}{cccccc}
\hline No & Kode Saham & $\beta_{1 i}$ & $\beta_{2 i}$ & $\beta_{3 i}$ & $\beta_{4 i}$ \\
\hline 1 & BBCA & $-0,0195$ & $-0,0002$ & 0,0114 & $-0,0075$ \\
2 & JSMR & 0,6577 & $-0,0001$ & $-0,0066$ & 0,0083 \\
3 & TLKM & 0,5439 & 0,0007 & $-0,0078$ & $-0,0147$ \\
\hline
\end{tabular}

Berdasarkan Tabel 5 dapat diamati bahwa nilai $\beta_{1 i}$ tertinggi diperoleh dari saham SRIL yaitu sebesar 0,6577 . Nilai $\beta_{2 i}$ tertinggi diperoleh dari saham TLKM yaitu sebesar 0.0007 . Nilai $\beta_{3 i}$ tertinggi diperoleh dari saham LPPF yaitu sebesar 0.0114. Dan nilai $\beta_{4 i}$ tertinggi diperoleh dari saham SRIL yaitu sebesar 0,0083.

\subsubsection{Expected Return}

Kemudian menghitung expected return dari masing-masing saham. Dengan menggunakan bantuan program $\mathrm{R}$, diperoleh hasil perhitungan expected return dari masingmasing saham seperti pada Tabel 6.

\begin{tabular}{|c|c|c|}
\hline No & Kode Saham & Expected Return \\
\hline 1 & LPPF & 0,0641 \\
\hline 2 & SRIL & 0,0303 \\
\hline 3 & TLKM & 0,0347 \\
\hline
\end{tabular}

Berdasarkan Tabel 6 dapat diamati bahwa nilai expected return tertinggi diperoleh dari saham LPPF yaitu sebesar 0,0641.

\subsubsection{Pembentukan Bobot Optimal}

Dengan menggunakan bantuan program $R$, diperoleh hasil seperti pada Tabel 7.

Tabel 7. Bobot Saham Optimal Masing-Masing Saham

\begin{tabular}{ccc}
\hline No & Saham & Bobot \\
\hline 1 & LPPF & 0,3239 \\
2 & SRIL & 0,4986 \\
3 & TLKM & 0,1775 \\
\hline
\end{tabular}

Berdasarkan tabel 7 dapat diketahui bahwa investor akan menginvestasikan dananya sebesar 32,39\% ke saham LPPF, sebesar 49,86\% ke saham SRIL dan sebesar 17,75\% ke saham TLKM.

\subsection{Penilaian Kinerja Portofolio}

Penilaian kerja portfolio bertujuan untuk mengetahui dan menganalisis apakah portofolio yang dibentuk telah dapat meningkatkan kemungkinan tercapainya tujuan investasi. Dalam penelitian ini penilaian kinerja portofolio menggunakan The Sharpe Index. Hasil perhitungan kinerja portofolio dengan menggunakan The Sharpe Index dapat dilihat pada Tabel 8. 
Tabel 8. Kinerja Portofolio

\begin{tabular}{ccccc}
\hline Model & $\bar{R}_{p}$ & $\sigma_{p}$ & $R_{b r}$ & The Sharpe Index \\
\hline CAPM & $-0,0015$ & 0,0445 & 0,0544 & $-1,2569$ \\
LCAPM & $-0,0151$ & 0,0591 & 0,0544 & $-1,1760$ \\
\hline
\end{tabular}

Berdasarkan tabel 8, diperoleh nilai The Sharpe Index untuk metode CAPM sebesar 1,2569 dan LCAPM sebesar -1,1760. Nilai kedua metode bernilai negatif yang menunjukkan bahwa kinerja portofolio dari masing-masing metode bukan yang terbaik. Hal ini dikarenakan nilai rata-rata return portofolio bernilai lebih kecil dari nilai rata-rata bebas risiko. Sehingga berdasarkan analisis kinerja portofolio menggunakan The Sharpe Index, hasil yang negatif menunjukan bahwa kinerja portofolio metode CAPM maupun LCAPM bukan yang terbaik. Akan tetapi jika kedua metode dibandingkan, kinerja portofolio pada metode LCAPM lebih baik dibandingkan dengan metode CAPM.

\subsection{Perbandingan Kinerja Portofolio}

Semakin besar angka yang diperoleh dari suatu portofolio maka semakin baik pula portofolio tersebut. Jadi dalam perbandingan portofolio yang dibentuk, portofolio yang memiliki indeks tertinggi merupakan portofolio yang optimal. Jika investor ingin menginvestasikan dananya ke portofolio yang terdiri dari tiga saham penyusun, maka portofolio yang paling optimal adalah portofolio saham model LCAPM dengan bobot investasi sebesar 32,39\% ke saham LPPF, sebesar 49,86\% ke saham SRIL dan sebesar $17,75 \%$ ke saham TLKM. Karena berdasarkan pengukuran kinerja menggunakan The Sharpe Index, dengan mempertimbangkan risiko $\sigma$, nilai The Sharpe Index portofolio model LCAPM sebesar -1,1760 lebih besar daripada nilai The Sharpe Index portofolio model CAPM sebesar $-1,2569$.

\section{KESIMPULAN}

Berdasarkan hasil analisis dan pembahasan yang telah dilakukan, maka dapat diperoleh kesimpulan, yaitu:

1. Portofolio yang terbentuk menggunakan model CAPM dengan 3 saham penyusun yaitu saham LPPF dengan bobot sebesar 7,57\%, SRIL dengan bobot sebesar $23,62 \%$ dan TLKM dengan bobot sebesar $68,81 \%$.

2. Portofolio yang terbentuk menggunakan model LCAPM dengan saham penyusun yang sama dengan metode sebelumnya yaitu saham LPPF dengan bobot sebesar 32,39\%, SRIL dengan bobot sebesar 49,86\% dan TLKM dengan bobot sebesar 17,75\%.

3. Berdasarkan kinerja portofolio dengan menggunakan The Sharpe Index diperoleh hasil bahwa kinerja portofolio untuk kedua metode tidak memberikan pilihan investasi yang terbaik. Akan tetapi jika membandingkan kinerja portofolio antara metode CAPM dan LCAPM, portofolio dengan model LCAPM lebih baik dibanding dengan model CAPM. Karena nilai The Sharpe Index LCAPM sebesar -1,1760 lebih besar daripada CAPM sebesar $-1,2569$.

\section{DAFTAR PUSTAKA}

Acharya, V. V. and Pederson, L. H. 2005. Asset Pricing with Liquidity Risk. Journal of Finansial Economics Vol. 77, No. 2 : Hal. 375-410.

Ahmad, K. 2004. Dasar-Dasar Manajemen Investasi dan Portofolio. Jakarta: PT Rineka Cipta.

Anoraga, P. dan Pakarti, P. 2006. Pengantar Pasar Modal. Jakarta: PT Rineka Cipta.

Apriyanti, V. dan Supandi, E. D. 2019. Perbandingan Model Capital Asset Pricing Model (CAPM) dan Liquidity Adjusted Capital Asset Pricing Model (LCAPM) dalam 
Pembentukan Portofolio Optimal Saham Syariah. Media Statistika Vol. 12, No.1 : Hal. 86-99.

Azis, M., Mintarti, S., dan Nadir, M. 2015. Manajemen Investasi. Yogyakarta: Deepublish.

Cahyati, N. 2015. Analisis Portofolio Optimum Saham Syariah Menggunakan Liquidity Adjusted Capital Asset Pricing Model (LCAPM). Jurnal Fourier Vol. 4, No.1 : Hal. 59-73.

Daniel, W. W. 1989. Statistik Nonparametrik Terapan. Diterjemahkan oleh: Alex Tri Kantjono W. Jakarta: PT Gramedia. Terjemahan dari: Applied Nonparametric Statistics.

Halim, A. 2005. Analisis Investasi. Jakarta: Salemba Empat.

Jogiyanto. 2017. Analisis Investasi dan Teori Portofolio. Yogyakarta: Gajah Mada Press (BPFE)

Mulyana, D. 2011. Analasis Likuiditas Saham serta Pengaruhnya terhadap Harga Saham pada Perusahaan yang Berada pada Indeks LQ-45 di Bursa Efek Indonesia. Jurnal Magister Manajemen Vol. 4, No.1 : Hal. 77-96.

Tandelilin, E.2010. Portofolio dan Investasi. Yogyakarta: Kanisius.

Zulfikar. 2016. Pengantar Pasar Modal dengan Pendekatan Statistika. Yogyakarta: Deepublish.

Zubir, Z. 2011. Manajemen Portofolio: Penerapan dalam Investasi Saham. Jakarta: Salemba Empat. 